\title{
Polydactyly and brachymetapody in two English families
}

\author{
SARAH B. HOLT \\ Galton Laboratory, University College, London
}

\begin{abstract}
Summary. Two new pedigrees of polydactyly associated with brachymetapody are described. In one the two defects occur in different members of the family, while in the other both occur in the same individuals. Both anomalies appear to be inherited as dominants, the polydactyly showing incomplete manifestation.
\end{abstract}

Polydactyly, the presence of extra digits on hands and feet, is a well-known structural anomaly. In man it is presumably due to a dominant gene. The expression is variable and normal overlapping occurs. Relatively frequently persons carrying the gene show no visible abnormality. Both hands and feet may have extra digits, but sometimes not all the extremities are affected and in some cases only one is abnormal. The defect varies considerably from family to family. Lewis (1909) wrote that polydactyly 'is most frequently post-axial (towards little finger or toe), but many varieties are known. Thus it may be pre-axial (towards thumb or great toe), in which case the hereditary tendency is probably less marked; or the duplication may be central.' The extra digits may be well developed or merely represented by small nodules. Sometimes polydactyly occurs with other defects of the hands and feet and sometimes alone. Bell (1953) considered the association of polydactyly with syndactyly and assembled the relevant pedigrees. Mohan (1969) described an Indian family where both polydactyly and ectrodactyly occurred.

Brachymetapody is the condition where one or more metacarpals or metatarsals are abnormally short. The term has been used by various authors (Koenner, 1934; Stiles, 1939; Steggerda, 1942; Gates, 1946) and the condition has been classified as a form of brachydactyly (Schinz, 1943; Bell, 1951), for the digits articulating with the shortened metacarpals or metatarsals appear short. The phalanges, however, are typically of normal length, al-

Received 25 November 1974. though brachymetapody may be combined with brachyphalangy (see for example Birkenfeld, 1928; Brailsford, 1945).

During the past 70 years brachymetapody has been described on numerous occasions, though it seems to be comparatively uncommon. A number of the descriptions are of isolated cases where nothing has been ascertained about the members of the families concerned. Various pedigrees, however, have been recorded. Bell (1951), who called the condition Type E brachydactyly, presented 15 pedigrees of brachymetapody from the literature. She also noted its occurrence in some members of three families showing other types of brachydactyly. In addition Davenport (1933) described a family showing three members with shortened metacarpals, while Koenner (1934) recorded a single case in an otherwise normal family.

The anomaly appears to be inherited as a dominant with incomplete manifestation. The expression is variable, ranging from unilateral cases where one metacarpal or metatarsal is short to those where three or even four metacarpals and metatarsals are affected bilaterally. The fourth metacarpals and metatarsals are the ones most frequently shortened. Among affected individuals there is a marked excess of females.

In three of the pedigrees polydactyly occurred as well as brachymetapody. Members of a family described by Mathew (1908) had short third, fourth, and fifth metacarpals associated with polydactyly of digit IV. It is not clear whether all the affected individuals had both defects. Biemond (1934) recorded a case of polydactyly (reduplication of the right thumb) in a family with much mental defect. 
The eldest son of a mentally defective mother had hereditary ataxia and polydactyly, while of his six sibs three had shortened metacarpals and metatarsals, digit IV being affected. The bone anomalies occurred only in this sibship and not in other relatives. Brailsford (1945) studied a family group showing numerous cases of brachymetapody. Some of the individuals had other bone defects and two women, cousins, with short metacarpals and metatarsals reported that each had been told that she was born with six fingers on each hand. These had been cauterized a few days after birth. It is not stated on which side of the hand the extra fingers were situated, but it seems probable that the polydactyly was post-axial.

Sverdrup (1922/1923) also found brachydactyly due to shortening of the metacarpals and metatarsals associated with post-axial polydactyly in a Norwegian family. The abnormality was always connected with 'A type' polydactyly, ie, where the extra digit was strongly developed, as contrasted with 'B type' where the extra digit was represented by a small, loosely attached appendage. Only polydactyl individuals showed the brachydactyly.

\section{The English pedigrees}

Two previously unrecorded pedigrees in which both polydactyly and brachymetapody occur are described. In the first the two abnormalities occur in different members of the family, while in the second both are present in the same individuals. There are polydactyl twins in both pedigrees.

In family 1 the polydactyly is post-axial, the duplication involving the fifth digit. The expression is variable, ranging from well-developed digits to loosely attached, boneless appendages. Hands and/or feet are affected. The brachymetapody takes the form of shortening of the fifth metacarpals in one member and of a short fourth metatarsal in two others.

In family 2 the polydactyly was post-axial on the hands of the living members and the third and fourth metacarpals are reduced in length. However, the propositus described his grandfather and his twin sister as having extra thumbs. On the feet the polydactyly is preaxial and is associated with syndactyly. When there is brachymetapody, it is limited to the second metatarsals.

\section{Family I (Fig. 1)}

I.1, 9. Digit $\mathrm{V}$ was reduplicated on both feet, but the extra toes were amputated. She has been blind for many years as a result of coloboma of the choroid and iris and retinal detachment. Her hand-prints were taken (Fig. 2). According to her, neither her mother nor her father had extra fingers or toes.

I.2, $\delta$. Hands and feet normal. His palm- and finger-prints were taken (Fig. 8).

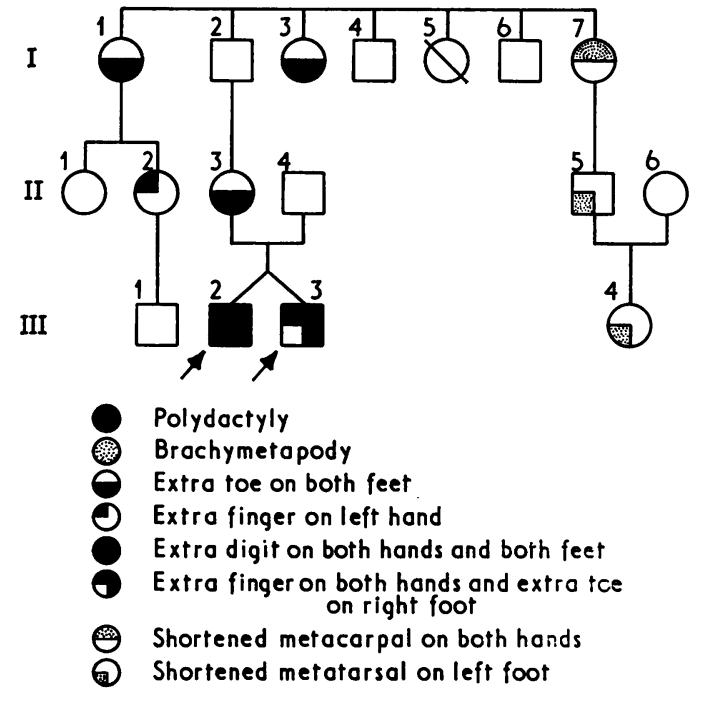

Frg. 1. Pedigree of family 1 with post-axial polydactyly in scme members and brachymetapody in others.

1.3 , o. Died at the age of 5 years. She is described by $I .1$ as having had 'six toes' on her feet.

I.4, $\$$. Hands and feet normal. He has been blind for many years; coloboma of the left iris. His palmand finger-prints were obtained (Fig. 8).

I.5, o. Died at 1 year. She is said to have had normal hands and feet. (Information from I.1 and I.2.)

I.6, $\delta$. Killed in the first world war. He is said to have had normal hands and feet.

I.7, 9 . She has a short fifth metacarpal on both hands, but no polydactyly. Her feet are normal. Her hands and feet were $x$-rayed (Fig. 2) and her palm- and finger-prints taken (Fig. 8).

II.1, ‥ Died of tuberculosis at the age of 23 years. According to her mother (I.1) she had normal hands and feet, but 'poor eye-sight'.

II.2, ㅇ. Had six fingers on her left hand (digit $\mathrm{V}$ reduplicated). The extra digit was amputated. Her feet are normal. Her palm- and finger-prints were taken (Fig. 8).

II.3, 9 . Had an extra little toe on each foot. These were amputated. Palm- and finger-prints were obtained (Fig. 8). Blood was typed for the ABO, MNS, Kell, and Lutheran blood-group systems; classification:

$$
\mathrm{O}, \mathrm{MsMs}, \mathrm{K}+, \mathrm{Lu}(\mathrm{a}-) \text {. }
$$

II.4, $\delta$ (husband of II.3) has normal hands and feet. He was blood-typed, classification:

$$
\mathrm{A}_{2}, \mathrm{NsNs}, \mathrm{K}+, \mathrm{Lu}(\mathrm{a}-) \text {. }
$$

II.5, $\delta$. His hands are normal, but metatarsal IV on his left foot is short. His right foot appears normal. His hands and feet were $x$-rayed (Fig. 3 ) and his palmand finger-prints were obtained (see Fig. 8). 


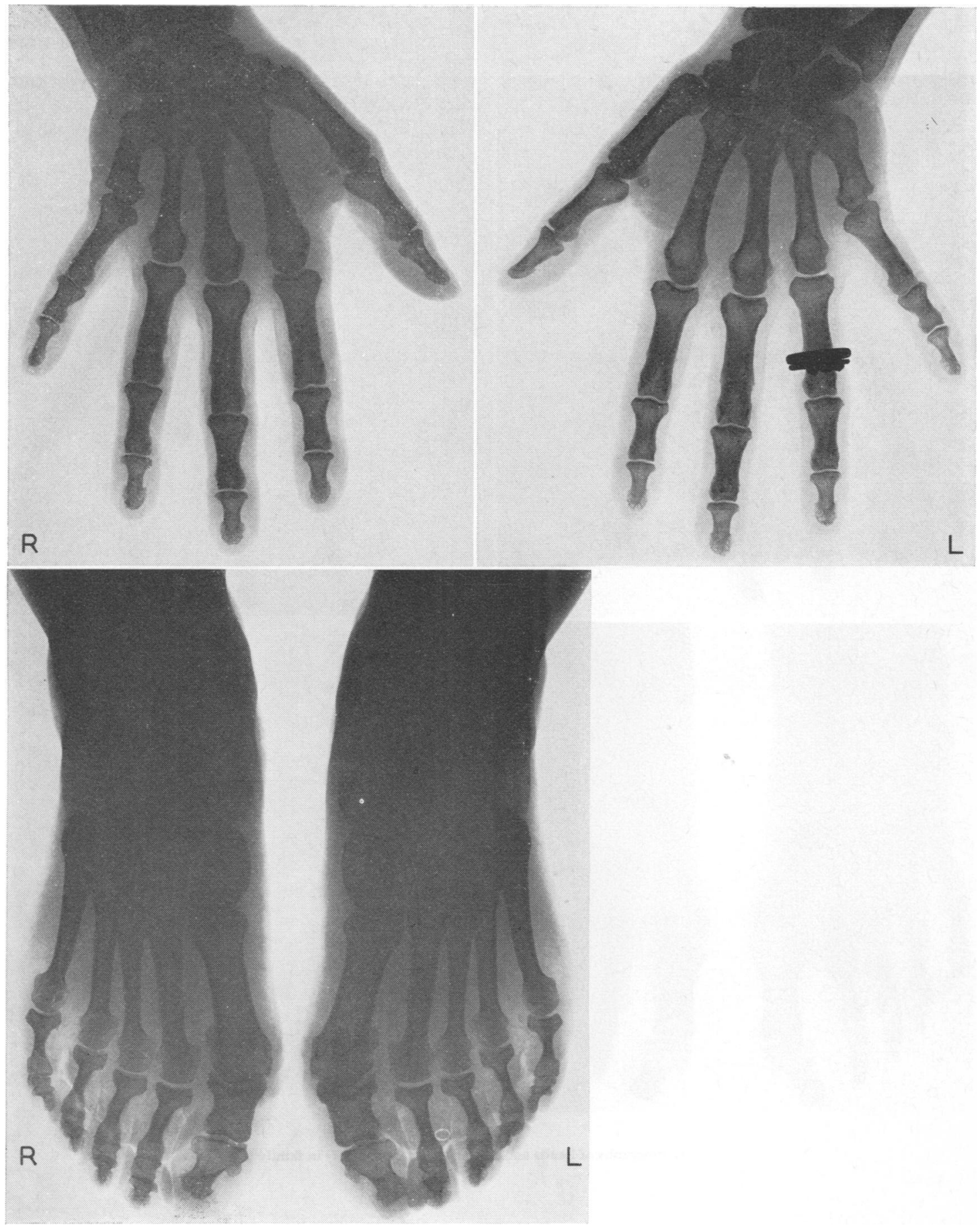

FIG. 2. Radiographs of hands and feet of I.7 (family 1). 

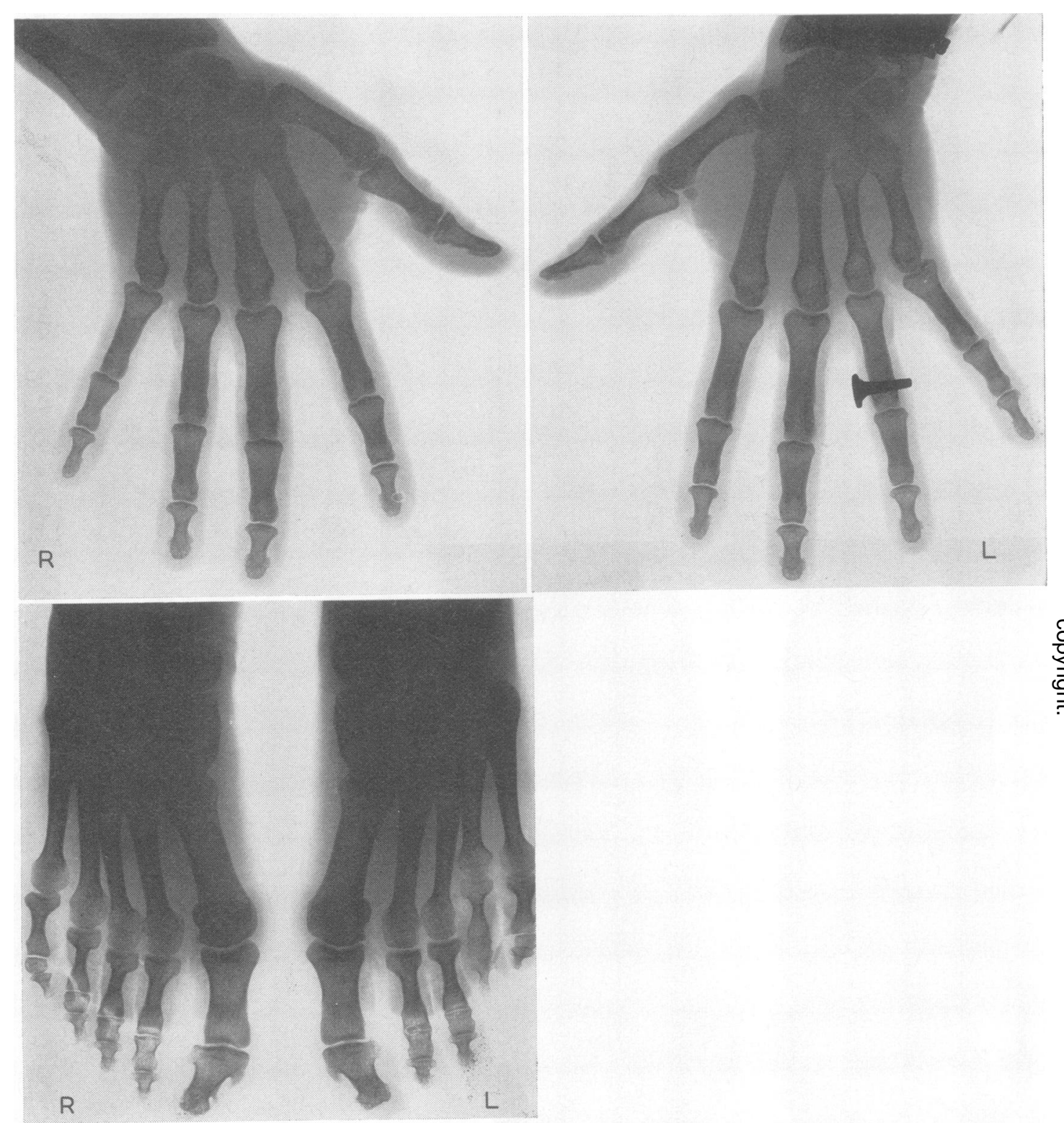

FIG. 3. Radiographs of hands and feet of II.5 $\sigma^{\hat{A}}$ (son of I.7) in family 1. 


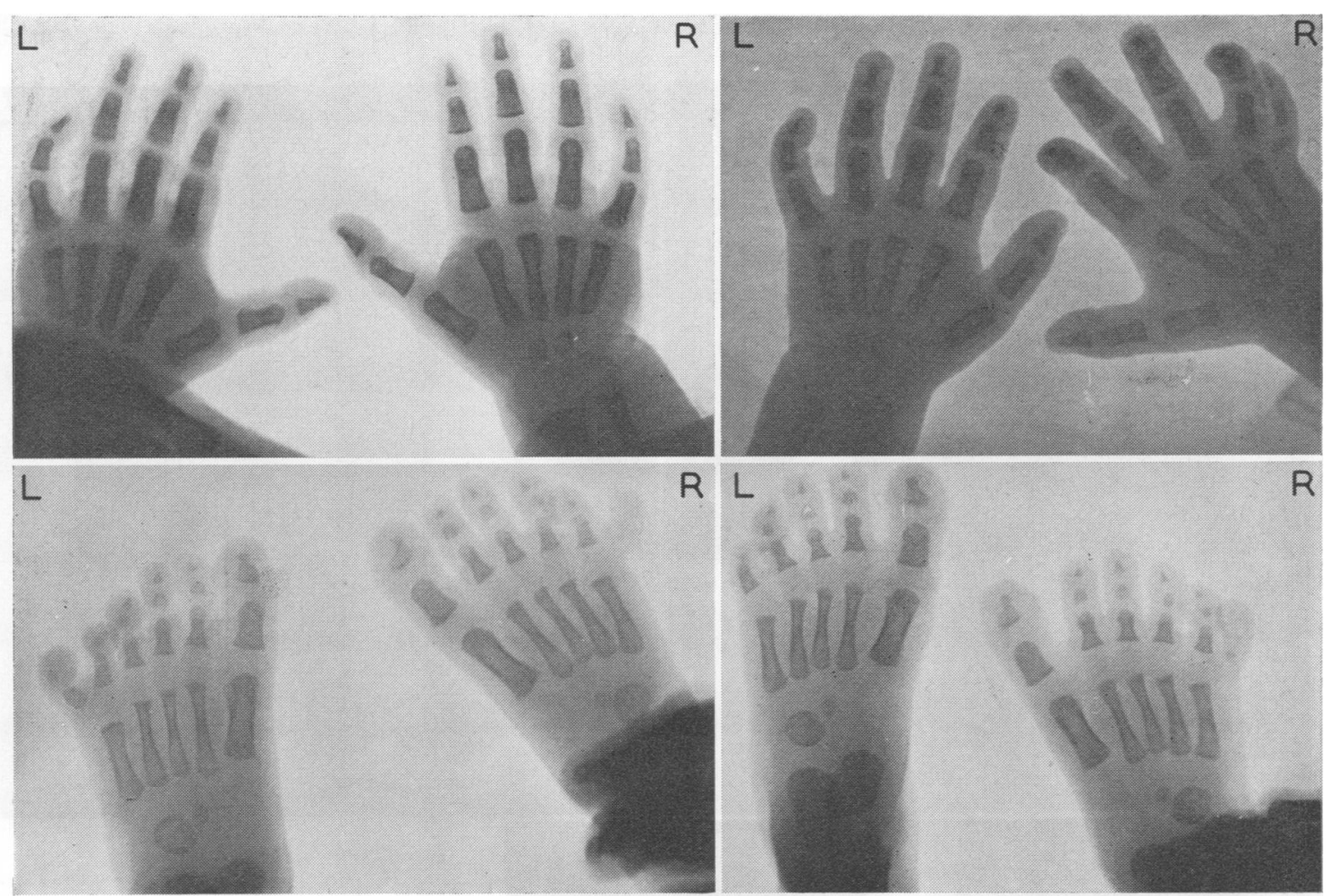

Fig. 4. Radiographs of hands and feet of the male twins III.2 and III.3 in family 1.

TABLE

FINGER RIDGE-COUNTS AND MAXIMAL atd ANGLES OF THE TWINS (III.2 AND III.3) IN FAMILY 1

Finger ridge-counts

\begin{tabular}{|c|c|c|c|c|c|c|c|c|c|c|c|}
\hline & \multicolumn{2}{|c|}{$\mathrm{v}$} & \multicolumn{2}{|c|}{ IV } & \multicolumn{2}{|c|}{ III } & \multicolumn{2}{|c|}{ II } & \multicolumn{2}{|c|}{ I } & \multirow{2}{*}{ Total } \\
\hline & $\mathbf{r}$ & $\mathbf{u}$ & $\mathbf{r}$ & $\mathbf{u}$ & $\mathbf{r}$ & $\mathbf{u}$ & $\mathbf{r}$ & $\mathbf{u}$ & $\mathbf{r}$ & $\mathbf{u}$ & \\
\hline $\begin{array}{l}I I I .2 \\
\text { Left }\end{array}$ & 13 & 0 & 16 & 9 & 13 & 14 & 13 & 15 & 14 & 0 & $72\}_{157}$ \\
\hline Right & 15 & 2 & 18 & 6 & 14 & 15 & 13 & 16 & 21 & 0 & $85 f$ \\
\hline $\begin{array}{l}I I I .3 \\
\text { Left }\end{array}$ & 15 & 2 & 17 & 9 & 12 & 10 & 1 & 10 & 17 & 0 & $71\}$ \\
\hline Right & 13 & 0 & 18 & 7 & 15 & 13 & 7 & 15 & 24 & 0 & $85\}$ \\
\hline
\end{tabular}

\begin{tabular}{cc|c|c|c}
\multicolumn{3}{c}{ atd angles } \\
\hline & Left & Right & Sum (both hands) \\
\hline III.2 & $0^{\circ}$ & $42^{\circ}$ & $41^{\circ}$ & $83^{\circ}$ \\
III.3 & $\sigma^{\circ}$ & $36^{\circ}$ & $44^{\circ}$ & $80^{\circ}$ \\
\hline
\end{tabular}




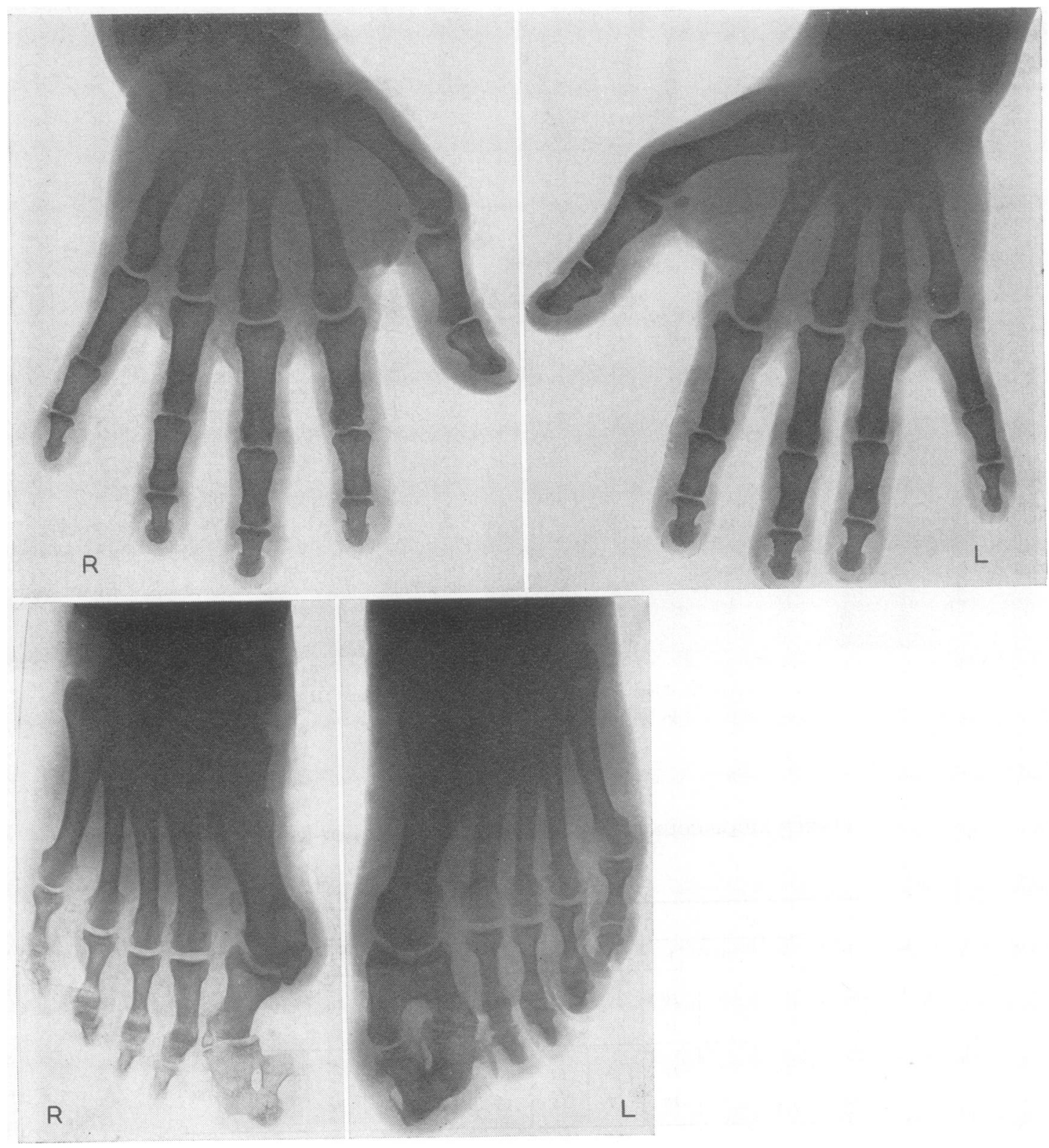

FIG. 5. Radiographs of hands and feet of III.3 of (family 2). 


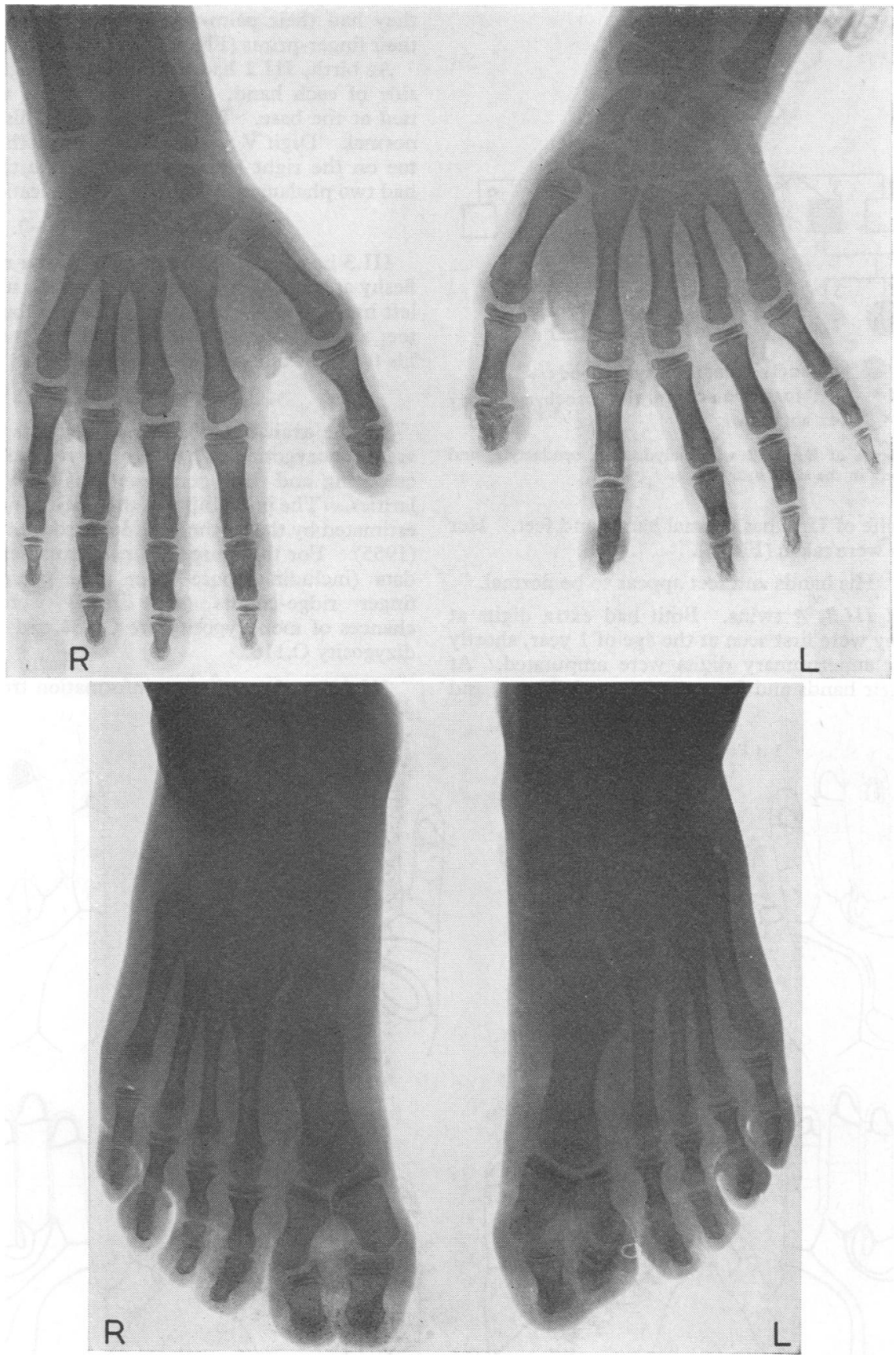

FIG. 6. Radiographs of hands and feet of IV.2 $q$ (family 2). 


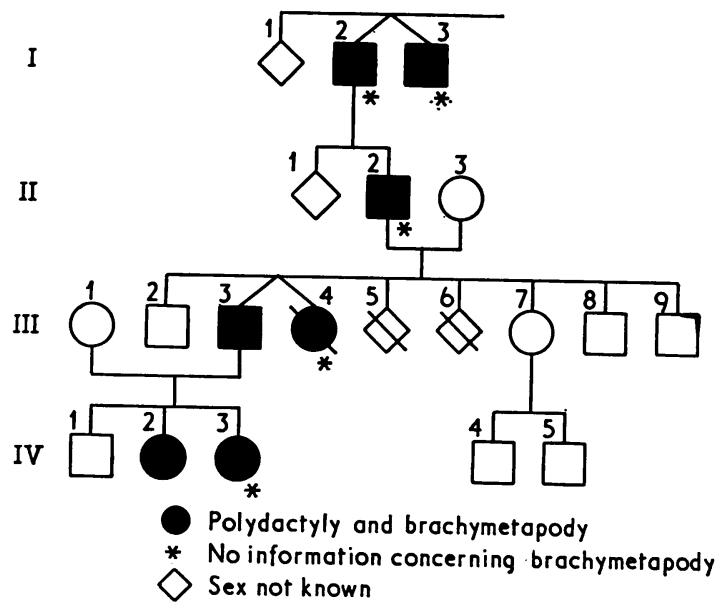

FIG. 7. Pedigree of family 2 with polydactyly, syndactyly, and brachymetapody in the same individuals.

II.6, ( (wife of II.5) has normal hands and feet. Her hand-prints were taken (Fig. 8).

III.1, $\delta$. His hands and feet appear to be normal.

III.2 and III.3, ot twins. Both had extra digits at birth. They were first seen at the age of 1 year, shortly before their supernumary digits were amputated. At this time their hands and feet were $x$-rayed (Fig. 4) and they were palm-printed, but proved uncooperative. Later they were blood-typed and, at the age of 5 years, they had their palm-prints taken again, together with their finger-prints (Fig. 8).

At birth, III.2 had a fleshy appendage on the ulnar side of each hand. These were easily removed when tied at the base. In the radiographs his hands appear normal. Digit $\mathrm{V}$ was duplicated on both feet, the extra toe on the right being boneless, while that on the left had two phalanges. His blood classification is:

$$
\text { O, MsNs, } \mathrm{K}+, \mathrm{Lu}(\mathrm{a}-) \text {. }
$$

III. 3 had digit $\mathrm{V}$ reduplicated on the right hand. $\mathrm{A}$ fleshy appendage was removed from the ulnar side of his left hand soon after birth. The right foot had an extra toe, almost boneless, the left foot being normal. Like his twin, his blood-type classification is:

$$
\text { O, MsNs, } \mathrm{K}+\text {, Lu (a-). }
$$

All the available information suggests that the twins $\vec{N}$ are monozygotic. They are very alike in looks and colouring and their dermatoglyphs show marked similarities. The probability of their being monozygotic was estimated by the method of Maynard Smith and Penrose (1955). For this purpose, apart from sex, blood-group data (including those from their parents) and total finger ridge-counts (see Table) were used. The chances of monozygosity are $\mathrm{O} .884$ and the chances of dizygosity 0.116 .

III.4, ․ According to information from her mother
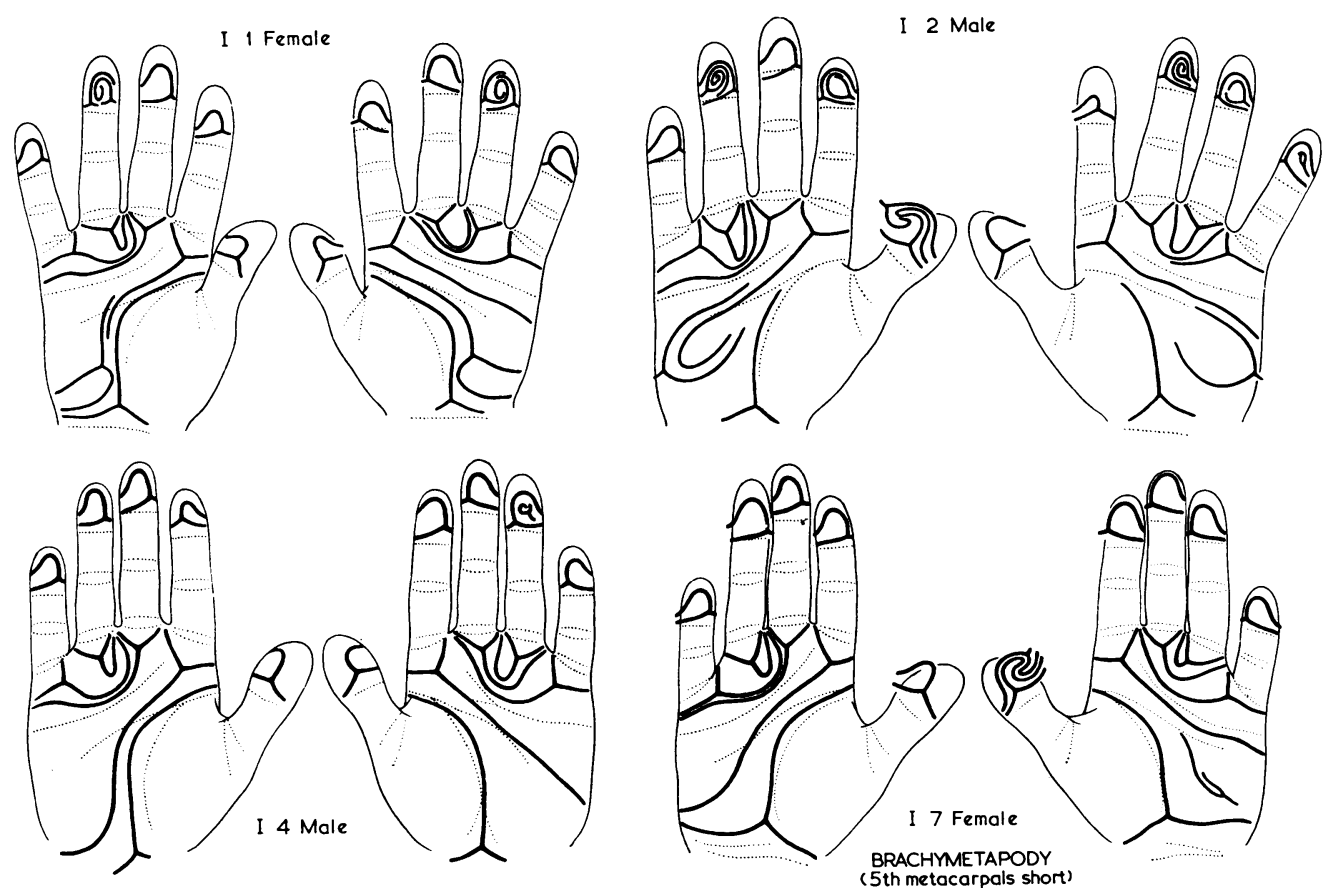

FIg. 8 (i). Dermatoglyphic configurations on hands and fingers of members of family 1. 

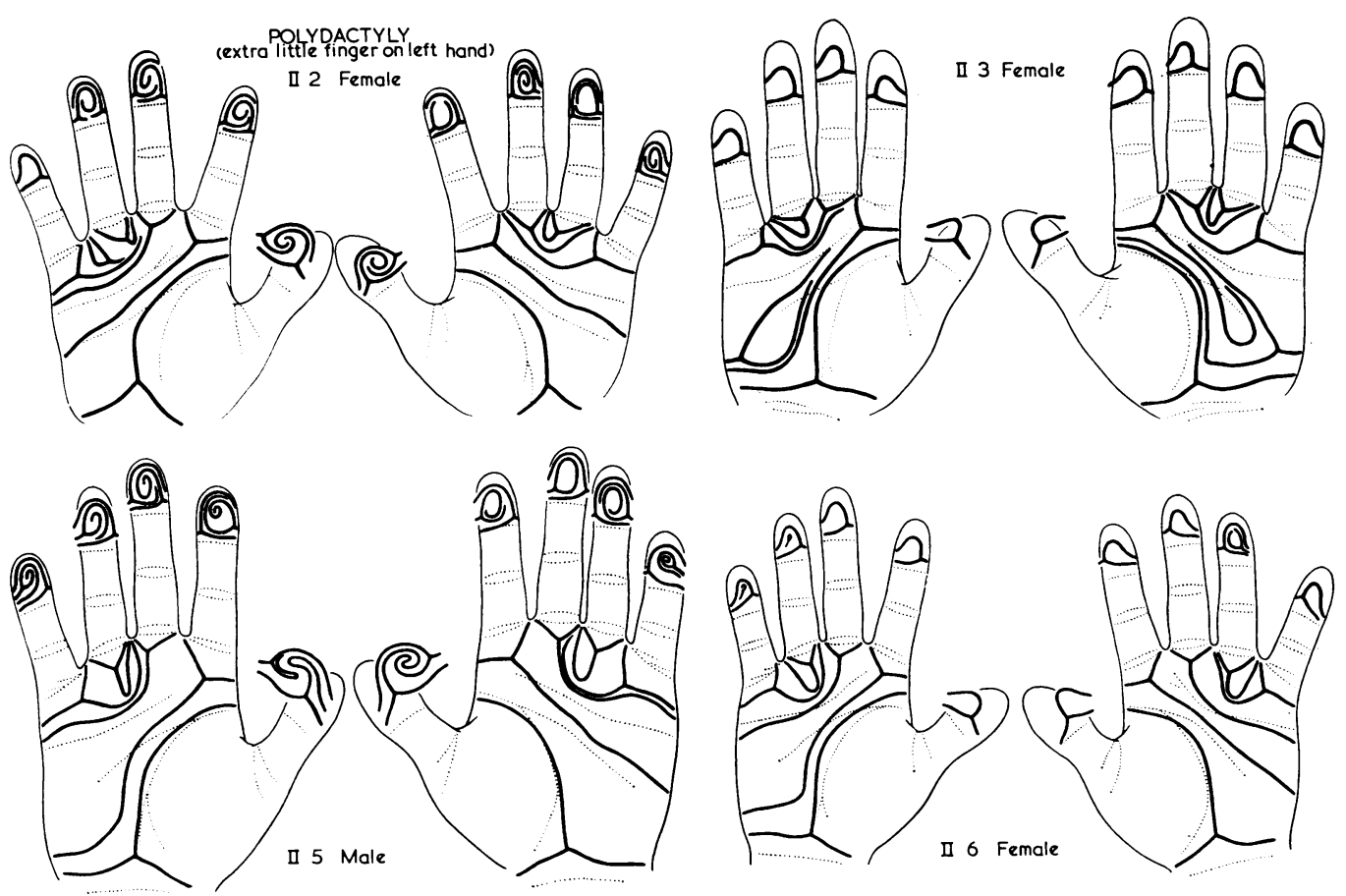

FIG. 8 (ii).
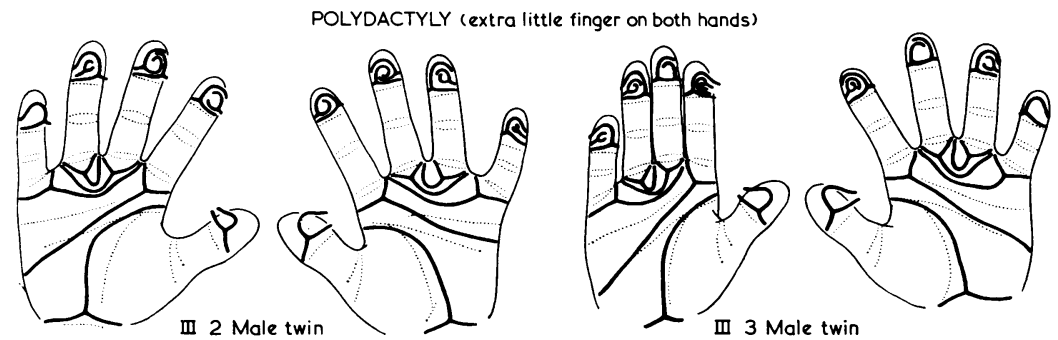

FIG. 8 (iii).

(II.6) and father (II.5) she has a shortened fourth metatarsal on her left foot, while her right foot and both hands are normal.

\section{Family 2 (Fig. 7)}

I.2 and I.3, ot twins. Both had polydactyly. I.2 was described by his grandson (III.3) as having had extra thumbs on both hands and double big toes similar to his own. I.3 lived to be an adult, but no details of his polydactyly are known. As far as III.3 is aware none of the twins' brothers and sisters had extra fingers and/or toes. He knew that one sib was older than his grandfather, but was uncertain of the sex.

II.2, đ. According to his son (III.3) he had double big toes similar to his own and extra fingers on both hands, digit $\mathrm{V}$ being reduplicated. In birth order, he was the second child. The sex of his elder sib is not known. He was said to be the only abnormal member of a large sibship. No further details are available.

II.3, + (the wife of II.2) had normal hands and feet, according to her son (III.3). She had two normal sons and a daughter by a second husband. This daughter has one child, a son with normal hands and feet.

III.1, + (the wife of III.3) had normal hands and feet. She died 6 months after the birth of her third child (IV.3). Her palm- and finger-prints were recorded some years earlier (Fig. 9).

III.2, ot died many years ago. His brother (III.3) said that he had normal hands and feet.

III.3, $\delta$ is the surviving member of a pair of dizygotic twins. He had an extra digit on the ulnar side of each 
hand, joined at the base of the little finger. These fingers were amputated. His hands are broad with shortened third and fourth metacarpals (Fig. 5). Both feet are extremely broad in proportion to their length and exhibit various abnormalities. The big toes are very broad with two complete nails on each. Radiographs (Fig. 5) show that there is duplication of the phalanges of these digits, the polydactyly being associated with syndactyly of the fleshy tissues. On the left foot the proximal phalanx of digit I is duplicated, though the bones are fused at the base. The terminal phalanx is also duplicated and the two phalanges are fused at the distal end. Digits II and III are almost completely joined to each other and to the polydactylous digit I by fleshy tissue. On the right foot the big toe has only one well-developed proximal phalanx, displaced towards the fibular side, but there is some bone on the tibial side near the head of the first metatarsal. The terminal phalanx is duplicated and there is fusion of these phalanges at the distal and proximal ends. On this foot also digits I, II, and III are almost completely joined to each other by fleshy tissue. There is some shortening of the second metatarsal bones of both feet. His finger- and palm-prints were recorded (Fig. 9).

III.4, ( (twin of III.3) died at the age of 1 year. She is said to have had 'double thumbs on both hands and double toes on both feet'.

III.5 and III.6 both died in early infancy. Sexes not known.

III.7, $q$ has no abnormalities of hands or feet. Her finger- and palm-prints were taken (Fig. 9).

III.8, $\sigma^{*}$ is dead. According to his brother (III.3) he had normal hands and feet.

III.9, ot lives abroad, so it has not been possible to see him. His brother (III.3) described him as having normal hands and feet.

$I V .1$, ot has normal hands and feet. His finger- and palm-prints were recorded (Fig. 9).

IV.2, ㅇ. Her hands are broad and short. She had an extra finger on each hand, joined to the little finger at the distal end of the proximal phalanx. These were amputated. When she was palm-printed at the age of 7 , scars were visible showing where the supernumerary digits had been attached. The third and fourth metacarpals on both hands are abnormally short (Fig. 6). Externally her feet are very similar to those of her father (III.3). Both big toes are very broad with two complete nails on each. On both feet digits II and III are almost completely joined by fleshy tissue, digit II on each foot also being joined to the polydactylous big toe. Radiographs (Fig. 6) show that on both feet the phalanges of the first digit are completely duplicated. There is no apparent shortening of the metatarsals. Her finger- and palm-prints were recorded (Fig. 9).

$I V .3$, ㅇ had extra little fingers, which were removed at an early age. She has double toes on both feet. Unfortunately, it was not possible to see her as she was taken to an institution at the age of 6 months after the death of her mother. The information about her hands and feet was provided by her father (III.3) and is obviously incomplete.

IV.4, ot has normal hands and feet. His finger- and palm-prints were taken (Fig. 9).

$I V .5, \delta$ also has normal hands and feet. His fingerand palm-prints were recorded (Fig. 9).

\section{Inheritance}

In both families polydactyly appears to be due to a dominant gene, with incomplete manifestation. Brachymetapody also is inherited as a dominant character.

\section{Dermatoglyphs}

Finger- and palm-prints were obtained from as many as possible of the members of both families.
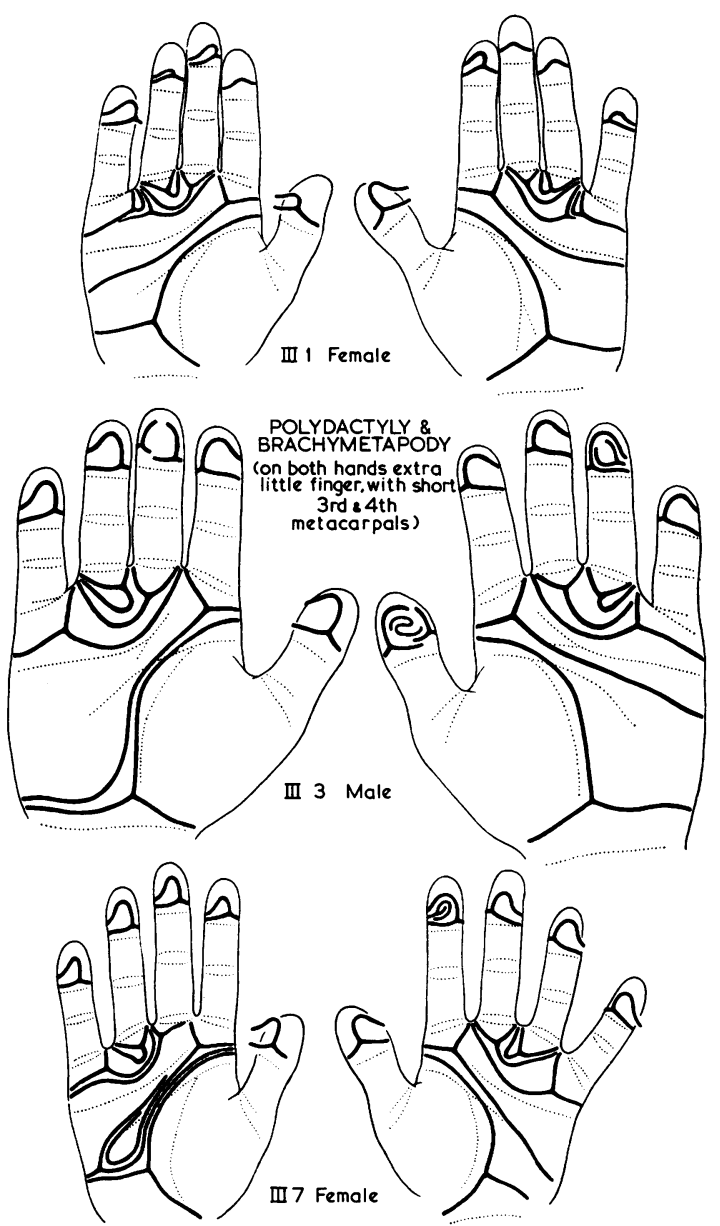

FIG. 9 (i). Dermatoglyphic configurations on hands and fingers of members of family 2 . 

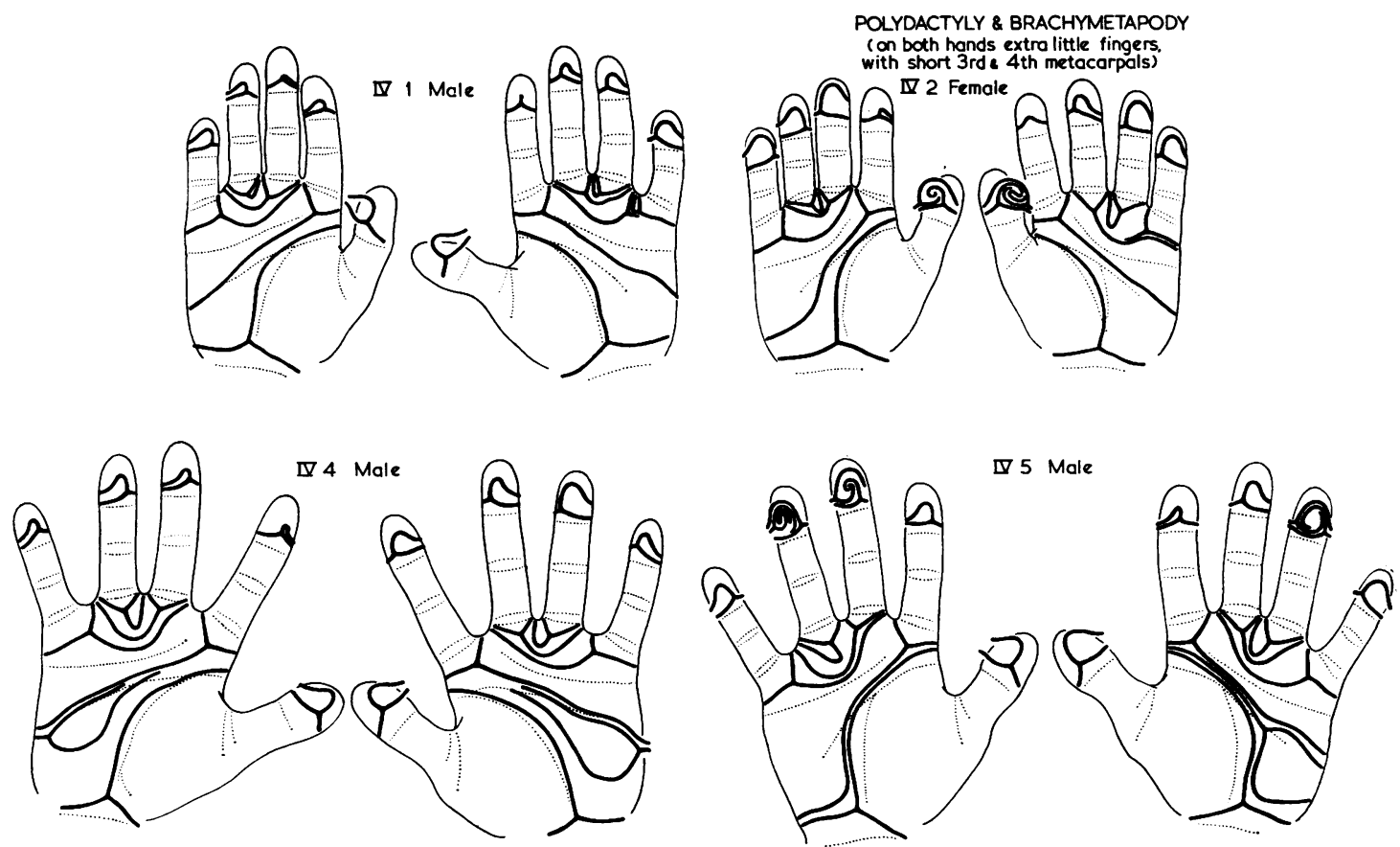

FIG. 9 (ii).

Unfortunately, although co-operative in other respects, none of these persons would agree to having their soles printed. Sole-prints of the twins in the first family and of the father and daughter with double big toes in the second would have been of particular interest.

Cummins (1943) wrote: 'In studying the inheritance of polydactyly an investigator meets with cases where the supernumerary digits, particularly if they are accessory to the little fingers, have been surgically removed or spontaneously amputated. The former existence of such a digit sometimes is recognizable by a scar, but often no scarring follows the amputation. Nevertheless, it is still possible to prove that there was once a supernumerary digit, since a triradius typically occurring in proximal relation to it remains as a permanent sign.' Sometimes on the palms of persons with polydactyly an extra digital triradius is found under the supernumerary finger, but by no means always (Holt, 1968). Unfortunately, in the families under consideration, of the five persons who had extra fingers only one has an additional digital triradius. Even one of the twins (III.3, family 1) who had a fairly well-developed supernumerary finger on the right hand (see Fig. 4), with a pattern on the ball has only four digital triradii on each hand. The one exception is II.2 in the first family, who had an accessory little finger amputated from her left hand. Her left palm-print (see Fig. 8) shows a fifth digital triradius in the fourth interdigital area between triradii $c$ and $d$, but as an indicator of polydactyly it is atypical.

When a supernumerary digit (finger or toe) is well developed, it bears a pattern. Patterns on the duplicated digits may be of the same type or of different types. Cummins (1926) used prints of the ridged skin of polydactyls and others with malformed hands and feet to study factors affecting ridge growth and differentiation. From these studies he concluded that when an extra toe, for instance, is imperfectly developed or is joined to its neighbour, the pattern on it is different from that of the neighbouring toe. Patterns of the same type tend to occur when reduplication is complete.

The pattern on the supernumerary finger of III.2 (family 1) was noted when he was first examined. It was an ulnar loop similar to the one on the neighbouring finger.

As far as can be ascertained, the palm-prints of the persons with brachymetapody are the first of this anomaly to be recorded. J. M. Donald (per- 
sonal communication) has recently taken prints, both palm and sole, of a mentally defective female patient with bilateral 'shortening of the third and fourth metacarpals and metatarsal bones'. The condition does not seem to be associated with any specific dermatoglyphic anomalies, such as those found in true brachydactyly, where one constant feature is a high frequency of simple arches on the fingers (Penrose and Holt, 1966).

I acknowledge with gratitude the assistance of colleagues who aided me in this investigation. I thank $\mathrm{Dr}$ P. C. Alexander for his radiographs of the twins (Fig. 4) and $\mathrm{Mr}$ A. J. Lee for his drawings.

\section{REFERENCES}

Bell, J. (1951). On brachydactyly and symphalangism. In Treastry of Human Inheritance, ed. by L. S. Penrose, Vol. 5, pt. 1. Cambridge University Press, London.

Bell, J. (1953). Syndactyly and its association with polydactyly. In Treasury of Human Inheritance, ed. by L. S. Penrose, Vol. 5, pt. II. Cambridge University Press, London.

Biemond, A. (1934). Brachydactylie, Nystagmus en Cerebellaire Ataxia als familiair syndroom. Nederlandsch Tijdschrift voor Geneeskunde, 78, 1423-1431.

Birkenfeld, W. (1928). Über die Erblichkeit der Brachyphalangie. Archiv für Klinische Chirurgie, 151, 611-631.

Brailsford, J. F. (1945). Familial brachydactyly. British fournal of Radiology, 18, 167-172.
Cummins, H. (1926). Epidermal-ridge configurations in developmental defects, with particular reference to the ontogenetic factors which condition ridge direction. American fournal of Anatomy, 38, 89-151.

Cummins, H. and Midlo, C. (1943). Finger Prints, Palms and Soles. Blakiston, Philadelphia.

Davenport, C. B. (1933). An alleged case of inheritance of acquired characters. American Naturalist, 67, 549-558.

Gates, R. R. (1946). Human Genetics. Macmillan, New York.

Holt, S. B. (1968). The Genetics of Dermal Ridges. Thomas, Springfield, Illinois.

Koenner, D. M. (1934). Abnormalities of hands and feet. Fournal of Heredity, 25, 329-334.

Lewis, T. (1909). Polydactylism. In Treasury of Human Inheritance, vol. 1, pts. I-II, pp. 10-14, ed. by K. Pearson. Cambridge University Press, London.

Mathew, P. W. (1908). A case of hereditary brachydactyly. British Medical fournal, 2, 969.

Maynard Smith, S. and Penrose, L. S. (1955). Monozygotic and dizygotic twin diagnosis. Annals of Human Genetics, 19, 273-289.

Mohan, J. (1969). Postaxial polydactyly in three Indian families. Fournal of Medical Genetics, 6, 196-200.

Penrose, L. S. and Holt, S. B. (1966). Note on dermatoglyphic data in a brachydactylous family. Annals of Human Genetics, 29, 383-388.

Schinz, H. R. (1943). Erbtypen und Formen bei Brachydaktylie. Archiv der fulius Klaus-Stiftung, 18, 361-404.

Steggerda, M. (1942). Inheritance of short metatarsals. Fournal of Heredity, 33, 233-234.

Stiles, K. A. (1939). The inheritance of brachymetapody. Fournal of Heredity, 30, 87-91.

Sverdrup, A. (1922/1923). Postaxial polydactylism in six generations of a Norwegian family. Fournal of Genetics, 12, 217-240. 